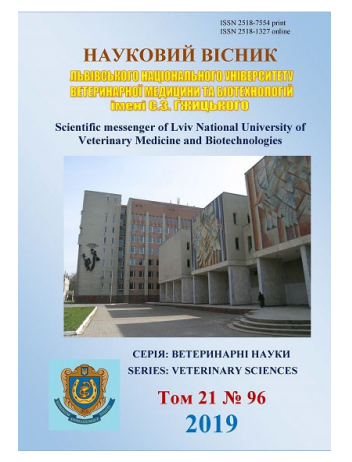

\author{
Науковий вісник Дьвівського націонадьного університету \\ ветеринарної медицини та біотехнологій імені С.3. Гжицького. \\ Серія: Ветеринарні науки
}
Scientific Messenger of Lviv National University of Veterinary Medicine and Biotechnologies. Series: Veterinary sciences

\title{
Stressor disorders of morphological indicators of bloods of ducks in critical periods of ontogenesis
}

\author{
A.O. Krogh, V.G. Stoyanovsky \\ Stepan Gzhytskyi National University of Veterinary Medicine and Biotechnologies Lviv, Ukraine
}

Article info

Received 08.10.2019

Received in revised form 12.11.2019

Accepted 13.11.2019

Stepan Gzhytskyi National University of Veterinary Medicine and Biotechnologies Lviv, Pekarska Str., 50, Lviv, 79010, Ukraine.

Tel.: +38-067-568-88-77

E-mail: anastasiiakrogh@gmail.com
Krogh, A.O., \& Stoyanovsky, V.G. (2019). Stressor disorders of morphological indicators of bloods of ducks in critical periods of ontogenesis. Scientific Messenger of Lviv National University of Veterinary Medicine and Biotechnologies. Series: Veterinary sciences, 21(96), 90-94. doi: $10.32718 /$ nvlvet 9616

The article presents data hematol ohichny performance blood of ducks in critical periods of postnatal ontogenesis 2, 14, 21, 45, 90, 150, and 240 days of life, which are accordingly related to the full use of the yolk, intensive development of the digestive system and muscular tissue, change of fluff to the primary feather, juvenile molt, the beginning of the oviposition, the formation of the reproductive system and glands of the internal secretion, the continuation of the oviposition and the molt, which is accompanied by the complete renewal of the fine and medium feathers. Blood plays an important role in maintaining homeostasis, and studies of hematological parameters make it possible to assess the intensity of redox processes in tissues and organs, and studies of hematological parameters make it possible to estimate the intensity of redox processes in tissues and organs, namely the need for oxygen in connection with the physico-chemical and biochemical processes that occur in the body in the process of growth and development. They are dynamic and change with different factors faster than performance. The purpose of the study was to determine the dynamics of morphological parameters of duck blood during the critical periods of postnatal ontogeny. Research subject clinically healthy young Beijing duck meat breed performance direction. Changes in hematological parameters of ducks' blood reflect a picture of the impact of critical periods of ontogeny on ducks, characterized by 2 days of life, the numerical values of erythrocytes $(2.45 \pm 0.11 \mathrm{~T} / \mathrm{l})$ and the concentration of hemoglobin $(102.90 \pm 3.51 \mathrm{~g} / \mathrm{l})$, but the value of hematocrit was in the lower levels of physiological norms. While the leukocyte count of $31.20 \pm 1.76$ was close to the 240-day age, indicating high bird immunity after hatching, more likely to come from the use of yolk. In the study bird on the 14th day recorded an increase in the number of erythrocytes and leukocytes by 10.6 and 14.7\%, hematocrit by $10.3 \%$ against a decrease in hemoglobin concentration by $12.8 \%(P<0.05)$. At 21 days, the number of erythrocytes and hemoglobin concentration decreased by $8.2 \%$, while hematocrit and leukocyte values approached the initial state of the experiment, amounting to $26.45 \pm 2.40 \%, 32.06 \pm 2.93 \mathrm{G} / \mathrm{L}$. The presence of basophils in this age period indicates the launch of a chain of immune responses, indicating the formation of the immune system according to A. Malyukin. (2010). At day 45, erythrocytes and hemoglobin concentrations were reduced by $10.2 \%$ and $11.3 \%(P<0.05)$, compared to the baseline period. During this period, hematocrit increased by $12.7 \%$, which indicated an increase in blood cells in the ducts. Results at 90 days indicated a decrease in erythrocyte count by $14.3 \%(P<0.05)$ and hemoglobin concentration by $11.8 \%(P<0.05)$, while leukocyte count and hematocrit increased by 26.1 and $22.1 \%(P<0.05)$ compared with ducklings of 2 days of age. In ducklings at 150 days of age, the erythrocyte count and hemoglobin concentration were close to the baseline, and the leukocyte count and hematocrit were increased by 19.6 and 39.3\%, respectively $(P<0.05)$. At 240 days of ducklings life, an increase in the oxygen-transport system of blood was established in the form of an increase in the number of erythrocytes by $35.1 \%(P<0.01)$, hemoglobin concentration by $28.7 \%(P<0.01)$, hematocrit value by $50,8 \%(P<0.01)$ compared to 2 -days of ducklings life, and the number of leukocytes was close to baseline, indicating a decrease in the reactivity of the organism.

Key words: erythrocytes, hemoglobin, hematocrit, leukogram, ontogeny, duckling. 


\title{
Стресорні порушення морфологічних показників крові качок у критичні періоди онтогенезу
}

\author{
А.О. Крог, В.Г. Стояновський
}

Львівський національний університет ветеринарної медицини та біотехнологій імені С.3. Гжиџького, м. Львів, Україна

У статті наведені дані гематологічних показників крові качок у критичні періоди постнатального онтогенезу на 2, 14, 21, 45, 90, 150, 240 добу життя, які відповідно пов'язані з повним використання жовтка, інтенсивним розвитком травної системи $і$ м'язової тканини, зміною пуху на первинне перо, ювенальною линькою, початком яйцекладки, формуванням репродуктивної системи $і$ залоз внутрішньої секреції, продовженням яйцекладки та линьки, яка супроводжується повним оновленням дрібного $і$ середнього пір'я. Важливу роль в підтриманні гомеостазу відіграє кров, а дослідження гематологічних показників дають можливість оцінювати інтенсивність окисно-відновних проиесів у тканинах та органах, а саме потребу в кисні у зв 'язку з фізико-хімічними та біохімічними процесами, які відбуваються в організмі в процесі росту і розвитку. Вони динамічні $і$ змінюються за дії різних чинників швидше, ніж показники продуктивності. Метою роботи було визначити динаміку морфологічних показників крові качок у критичні періоди постнатального онтогенезу. Дослідженню підлягав клінічно здоровий молодняк пекінської породи качок м'ясного напрямку продуктивності. Зміни гематологічних показників крові качок відображають нам картину впливу критичних періодів онтогенезу на організм качок, щчо характеризуються на 2 добу життя - числові значення еритроцитів (2,45 \pm 0,11 Т/л) та концентрачії гемоглобіну $(102,90 \pm 3,51$ г/л), проте величина гематокриту перебувала у нижчих рівнях фізіологічної норми. Кількість

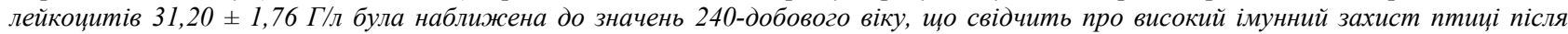
вилуплення, найімовірніше отриманий від використання жовтка. У досліджуваній птиці на 14 добу реєстрували підвищення кількості еритрочитів і лейкоцитів на 10,6 і 14,7\% , величини гематокриту на 10,3\% на тлі зменшення концентрації гемоглобіну на 12,8\% (P< 0,05). На 21 добу кількість еритрочитів та кониентрачія гемоглобіну знижувалася на 8,2\%, тимчасом як величина

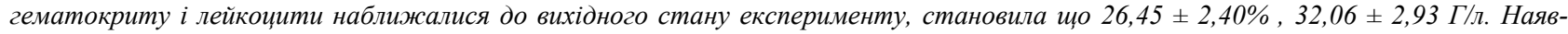
ність базофілів у цььому віковому періоді свідчить про запуск ланцюгу імунних реакиій, шьо вказує на становлення імунної системи. На 45 добу в каченят виявлено зменшення кількості еритроцитів і концентрацї гемоглобіну на 10,2\% та 11,3\% (P < 0,05) порівняно з вихідним періодом. В ией період величина гематокриту підвищувалась на 12,7\%, щчо вказувало на збільшення формених елементів крові у кровоносному руслі каченят. Отриманні результати на 90 добу життя вказували на зниження кількості еритроцитів на 14,3\% (P<0,05) та концентрація гемоглобіну на 11,8\% (P<0,05), тимчасом як кількість лейкоцитів і величина гематокриту зростали на 26,1 і 22,1\% (P < 0,05) порівняно з каченятами 2-добового віку. В каченят на 150 добу життя кількість еритрочитів та кониентрачія гемоглобіну наближалась до вихідного періоду експерименту, а кількість лейкочитів $і$ величина гематокриту підвищувалась на 19,6 і 39,3\% (P < 0,05). На 240 добу життя каченят встановлено підвищення киснево-транспортної системи крові у вигляді зростання кількості еритроцитів на 35,1\% (P<0,01), концентрації гемоглобіну на 28,7\% $(P<0,01)$, величини гематокриту на 50,8\% (P < 0,01) порівняно з 2-добовими каченятами, а кількість лейкоцитів наближалось до вихідного стану, цчо свідчило про зниження реактивності організму.

Ключові слова: еритроцити, гемоглобін, гематокрит, лейкограма, онтогенез, каченята.

\section{Ветуп}

Визначення кількісних характеристик показників крові є невід'ємною частиною клінічних досліджень і дає добре розуміння інтенсивності еритропоезу i морфофункціонального стану клітин крові в критичні періоди онтогенезу (Stojanovskij et al., 2012; Kolomiec, 2013; Hariv \& Gutyj, 2017; Khariv et al., 2017; Stojanovskij et al., 2018). Як зазаначає Тельцов Л.П. (Tel'cov, 2003), фізіологічні аспекти функціонування організму качок доцільно досліджувати у критичні періоди росту і розвитку. На думку дослідника, критичні періоди розвитку виявляються на межі етапів, періодів і рідше стадій розвитку птиці, тому кожна критична фаза обумовлює процеси детермінованого, інтегрованого асинхронного і гетерохронного розвитку в онтогенезі. Дослідження критичної періодизації має важливе значення у ветеринарії та біології розмноження і розвитку (Kryshtoforova \& Lemeshchenko, 2008; Vishhur et al., 2010; Wójcik \& Smalec, 2017). Дослідженню морфофункціональних показників крові в організмі качок в різні періоди постнатального онтогенезу присвячені роботи (Olayemi et al., 2002; Olubodun et al., 2015; Pavlova, 2015; Chen et al., 2018). Як зазначає Малюкін А.В. (2010), параметри гематологі- чних показників в постнатальному періоді онтогенезу качок змінюються з різною періодичністю. За даними автора, високі значення гематокриту, кількості еритроцитів і рівня гемоглобіну в крові каченят раннього постнатального онтогенезу (до першого місяця життя) обумовлені адаптацією птахів до умов середовища існування та інтенсивними процесами обміну речовин, а збільшення кількості лейкоцитів пов'язане зі становленням імунної системи.

Мета нашої роботи було з'ясувати динаміку морфологічних показників крові качок у критичні періоди постнатального онтогенезу. Підсумовуючи наведені вище літературні повідомлення стосовно функціонування організму качок в критичні періоди постнатального онтогенезу, варто підкреслити актуальність проведення дослідження основних параметрів їх фізіологічного стану, систематизації отриманих результатів, підтвердження та удосконалення системи оцінювання за тими показниками, які залишилися поза увагою дослідників. У зв'язку з цим, дослідження гематологічних особливостей функціонування організму пекінських качок, ми можем аналізувати формування їх реактивності. 


\section{Матеріал і методи досліджень}

Дослід проведено в умовах ДП ДГ “Миклашівське” (с. Миклашів Пустомитівського району Львівської області, Україна) на клінічно здоровому молодняку качок пекінської породи м'ясного напряму продуктивності. Утримання птиці відповідало загальноприйнятим технологічним вимогам комбінованого вирощування на відгодівельних майданчиках і в таборах (вигульне утримання з вільним доступом до напувалок та годівниць). Температурний та світловий режими відповідали рекомендованим нормам. Уся птиця одержувала стандартний комбікорм, збалансований за поживними і біологічно активними речовинами, який рекомендований для даного віку згідно з технологією утримання. Для досягнення поставленої мети в однодобовому віці сформовано групу в кількості 1000 особин, відбір птиці для забою проводили у критичні періоди постнатального онтогенезу, які збігаються на: 2 добу життя (повне використання жовтка), 14 добу життя (інтенсивний розвиток травної системи і м'язової тканини), 21 добу життя (зміна пуху на первинне перо), 45-90 доба життя (ювенальна линька), 150 добу життя (початок яйцекладки, формування репродуктивної системи і залоз внутрішньої секреції), 240 добу життя (продовження яйцекладки та линька, яка супроводжується повним оновленням дрібного і середнього пір'я). Після легкого ефірного наркозу методом гострого знекровлення був проведений забій по 5 каченят у кожному віковому періоді та відібрано для досліджень кров до ранкової годівлі.

Усі втручання з качками проводили з дотриманням вимог "Свропейської конвенції про захист хребетних тварин, які використовуються для експериментальних і наукових цілей” (Страсбург, 1986), ухвали Першого національного конгресу з біоетики (Київ, 2001) - “Загальні етичні принципи експериментів на тваринах" та 3 дотриманням принципів гуманності, викладених у директиві Європейської Спільноти.
У гепаринізованій крові визначали: кількість еритроцитів та лейкоцитів у лічильній сітці камери Горяєва; лейкограму крові - шляхом підрахунку та диференціації клітин лейкоцитів у мазках крові, пофарбованих за методом Романовського-Гімзи; концентрацію гемоглобіну - гемоглобінціанідним методом, величину гематокриту - капілярним методом (Vlizlo et al., 2012). Визначення морфологічних показників крові, лейкограми, імунологічних показників організму качок виконані у лабораторії клініко-біологічних досліджень відділу фармакології та імуноморфології Державного науково-дослідного контрольного інституту ветеринарних препаратів та кормових добавок. Різниці статистично вірогідними вважали при $\mathrm{P}<0,05$ $-^{*}, \mathrm{P}<0,01-* *, \mathrm{P}<0,001-* * *$ порівняно 3 вихідним віковим періодом.

\section{Результати та їх обговорення}

Отримані результати дослідження морфологічних показників крові качок у критичні періоди постнатального онтогенезу наведені у таблицях 1 та 2. Аналізуючи цифровий матеріал таблиці 1, варто зазначити, що у 2-добових каченят кількість еритроцитів становила $(2,45 \pm 0,11 \mathrm{~T} / л)$, концентрація гемоглобіну $(102,90 \pm 3,51$ г/л), разом 3 тим величина гематокриту перебувала у нижніх межах фізіологічної норми.

На 14 добу життя у крові каченят виявлено підвищення кількості еритроцитів на 10,6\% i величини гематокриту на 10,3\%, що вказувало на інтенсивний еритроцитопоез порівняно 3 каченятами 2-добового віку. Проте спостерігалося зменшення концентрації гемоглобіну на $12,8 \%$ (P < 0,05$)$, що свідчило про зниження киснево-транспортної функції крові і могло бути ознакою критичного вікового періоду.

\section{Таблиця 1}

Морфологічні показники крові качок у критичні періоди постнатального онтогенезу $(\mathrm{M} \pm \mathrm{m}, \mathrm{n}=5)$

\begin{tabular}{cccc}
\hline Вік, доба & Кількість еритроцитів, Т/л & Концентрація гемоглобіну, г/л & Величина гематокриту, \% \\
\hline 2 & $2,45 \pm 0,11$ & $102,90 \pm 3,51$ & $26,21 \pm 1,80$ \\
14 & $2,71 \pm 0,19$ & $89,75 \pm 2,82^{*}$ & $28,90 \pm 2,12$ \\
21 & $2,25 \pm 0,13$ & $93,65 \pm 2,63$ & $26,45 \pm 2,40$ \\
45 & $2,20 \pm 0,21$ & $91,25 \pm 2,16^{*}$ & $29,54 \pm 2,70$ \\
90 & $2,10 \pm 0,09^{*}$ & $90,81 \pm 2,70^{*}$ & $32,01 \pm 1,57 *$ \\
150 & $2,43 \pm 0,17$ & $107,46 \pm 3,40$ & $36,67 \pm 2,93^{*}$ \\
240 & $3,31 \pm 0,25^{* *}$ & $132,45 \pm 4,69^{* *}$ & $39,52 \pm 2,16^{* *}$ \\
\hline Р $<0,05 ; * *-\mathrm{P}<0,01 ; * * *-\mathrm{P}<0,001$ & & &
\end{tabular}

У 21-добовому віці кількість еритроцитів знижувалася на 8,2\%, а величина гематокриту наближалася до вихідного періоду експерименту i становила $26,45 \pm 2,40 \%$. На 9,0\% виявилася нижчою концентрація гемоглобіну в 21-добових каченят, що вказувало на напруженість окисно-відновних процесів в їхньому організмі. На 45 добу життя в крові каченят кількість еритроцитів та концентрація гемоглобіну зменшувалася на 10,2\% і $11,3 \%$ ( $>0,05)$ порівняно з вихідним станом, що було ознакою зниження насичення тканин киснем. В цей період величина гематокриту підвищувалася на $12,7 \%$, що вказувало на збільшення формених елементів крові у кровоносному руслі каченят. На 90 добу життя серед досліджуваних критичних періо- 
дів установлено найнижче числове значення кількості еритроцитів у крові молодняку качок, що складало $2,10 \pm 0,09$ Т/л та було нижчим на $14,3 \%(\mathrm{P}<0,05)$ порівняно 3 каченятами 2-добового віку. На 11,8\% $(\mathrm{P}<0,05)$ виявилася нижчою концентрація гемоглобіну в 90-добових каченят, що могло бути ознакою критичного вікового періоду. Проте кількість формених елементів крові молодняку качок 90-добового віку збільшувалася, на що вказує підвищення величини гематокриту на $22,1 \%(\mathrm{P}<0,05)$ порівняно 3 каченятами 2-добового віку.

На 150 добу життя в крові качок кількість еритроцитів та концентрація гемоглобіну наближалися до вихідного періоду експерименту, що було ознакою відновлення еритроцитопоезу, а величина гематокри- ту підвищувалася на 39,3\% (P < 0,05). Отримані значення не виходили за фізіологічні межі нормативних даних для качок. У 240-добовому віці встановлено підвищення киснево-транспортної функції крові качок у вигляді зростання на $35,1 \%(\mathrm{P}<0,01)$ кількості еритроцитів і на $28,7 \%(\mathrm{P}<0,01)$ концентрації гемоглобіну. Підвищення величини гематокриту на 50,8\% $(\mathrm{P}<0,01)$ не виходило за верхні межі фізіологічної норми для качок і було ознакою кровотворної функції їхнього організму. Наші результати не зовсім узгоджуються $з$ даними літератури, де зазначено, що гематокрит та вміст гемоглобіну значно підвищується у качурів протягом періоду росту і знижується в період статевої активності.

\section{Таблиця 2}

Кількість лейкоцитів і величина лейкограми крові качок у критичні періоди постнатального онтогенезу, \% $(\mathrm{M} \pm \mathrm{m}, \mathrm{n}=5)$

\begin{tabular}{ccclccc}
\hline $\begin{array}{c}\text { Вік, } \\
\text { доба }\end{array}$ & $\begin{array}{c}\text { Загальна кількість } \\
\text { лейкоцитів, Г/л }\end{array}$ & Базофіли & Еозинофіли & $\begin{array}{c}\text { Псевдо- } \\
\text { еозинофіли }\end{array}$ & Лімфоцити & Моноцити \\
\hline 2 & $31,20 \pm 1,76$ & - & $1,8 \pm 0,54$ & $37,0 \pm 2,05$ & $59,0 \pm 2,57$ & $2,2 \pm 0,66$ \\
14 & $35,82 \pm 2,50$ & - & $4,4 \pm 0,93$ & $31,2 \pm 2,91$ & $62,2 \pm 4,15$ & $2,2 \pm 0,97$ \\
21 & $32,06 \pm 2,93$ & $2,2 \pm 0,49$ & $3,8 \pm 0,77$ & $28,2 \pm 2,23^{*}$ & $62,4 \pm 4,49$ & $3,4 \pm 0,53$ \\
45 & $33,70 \pm 2,10$ & - & $5,2 \pm 0,65^{* *}$ & $35,2 \pm 3,08$ & $57,6 \pm 3,05$ & $2,0 \pm 0,28$ \\
90 & $39,33 \pm 2,05^{*}$ & - & $6,0 \pm 0,88^{* *}$ & $39,6 \pm 2,69$ & $50,0 \pm 2,70^{*}$ & $4,4 \pm 0,50^{*}$ \\
150 & $37,33 \pm 1,85^{*}$ & - & $5,2 \pm 0,70^{* *}$ & $38,6 \pm 3,50$ & $51,0 \pm 2,80^{*}$ & $5,2 \pm 0,98^{*}$ \\
240 & $31,55 \pm 2,19$ & - & $7,8 \pm 0,99 * *$ & $35,2 \pm 2,74$ & $50,8 \pm 2,61^{*}$ & $6,2 \pm 0,80^{* * *}$ \\
\hline
\end{tabular}

Аналізуючи дані таблиця 2, варто зазначити, що на 2 добу життя каченят загальна кількість білих клітин відповідала величині 240-добового віку і складала $31,20 \pm 1,76$ Г/л і 31,55 $\pm 2,19$ Г/л. Лейкограма крові птахів даного вікового періоду характеризувалася величинами, які перебували в межах фізіологічної норми, зокрема: частка еозинофілів становила $1,8 \pm 0,54 \%$, псевдоеозинофілів - 37,0 $\pm 2,05 \%$, лімфоцитів - 59,2 $\pm 2,57 \%$, моноцитів - 2,2 $\pm 0,66 \%$.

У 14-добовому віці кількість лейкоцитів в крові каченят підвищувалася на 14,7\% за рахунок збільшення в 3,7 разу еозинофілів та в 1,1 разу лімфоцитів, що вказувало на становлення імунної системи. В цей період кількість специфічних форм клітин крові, характерних для птиці, - псевдоеозинофілів знижувалася до $31,2 \pm 2,91 \%$. На 21 добу життя у крові каченят кількість лейкоцитів знижувалася на 2,8\% за рахунок вірогідного зниження кількості псевдоеозинофілів у 0,8 разу $(\mathrm{P}<0,05)$, що могло бути ознакою зниження інтенсивності фагоцитозу, оскільки ці клітини є активними бактеріальними фагоцитами в крові і тканинах. В досліджуваний критичний період серед видів лейкоцитів крові каченят виявлено базофіли, частка яких складала $2,2 \pm 0,49 \%$. Їхня поява могла свідчити про активацію обміну речовин в сполучній тканині, а також про розвиток імунних реакцій неспецифічного характеру. На це вказувало і зростання співвідношення моноцитів до $3,4 \pm 0,53 \%$ та еозинофілів в 3,2 разу. Кількість лімфоцитів була стабільно вищою в 1,1 разу порівняно з вихідним віковим періодом.

На 45 добу життя кількість лейкоцитів в крові ка- ченят підвищувалася на 8,0\% за рахунок збільшення в 4,3 разу еозинофілів $(\mathrm{P}<0,05)$ порівняно з 2-добовою птицею. Кількість інших видів лейкоцитів зменшувалася, зокрема псевдоеозинофілів та лімфоцитів в 0,9 разу, а кількість моноцитів залишалася на рівні вихідного періоду експерименту, що могло вказувати на зниження інтенсивності фагоцитозу. На 90 добу життя в крові качок спостерігали зростання кількості лейкоцитів на $26,1 \%(\mathrm{P}<0,05)$ за рахунок збільшення в 5 разів еозинофілів $(\mathrm{P}<0,01)$ та в 2,2 разу моноцитів $(\mathrm{P}<0,05)$. Такий перерозподіл міг бути ознакою активації клітинної ланки неспецифічної резистентності та імунологічної реактивності організму качок. Кількість псевдоеозинофілів у крові качок була стабільно вищою в 1,1 разу порівняно з вихідним віковим періодом. У 90-добових качок виявляли зменшення кількості лімфоцитів в 0,8 разу $(\mathrm{P}<0,05)$ - як ознаку пригнічення гуморальної ланки імунного захисту їхньго організму.

На 150 добу життя кількість лейкоцитів у крові качок була стабільно вищою на $19,6 \%(\mathrm{P}<0,05)$ за рахунок збільшення в 2,9 разу еозинофілів $(\mathrm{P}<0,01)$ та в 2,4 разу моноцитів $(\mathrm{P}<0,01)$ порівняно $з 2$-добовою птицею. Частка псевдоеозинофілів наближалася до вихідного періоду експерименту і складала $38,6 \pm 3,50 \%$. Установлено зменшення кількості лімфоцитів в 0,9 разу $(\mathrm{P}<0,05)$, що свідчило про подальше зниження імунного статусу організму качок. У 240-добовому віці встановлено зменшення кількості лейкоцитів у крові качок порівняно 3 попередніми віковими періодами та наближення до числових пока- 
зників каченят 2-добового віку. Перерозподіл різних видів білих клітин крові качок відбувався у вигляді збільшення в 4,3 разу еозинофілів $(\mathrm{P}<0,001)$ та в 2,8 разу моноцитів $(\mathrm{P}<0,001)$ на тлі зменшення аналогічних показників лімфоцитів в 0,9 разу $(\mathrm{P}<0,05)$. Кількість псевдоеозинофілів знижувалася до $35,2 \pm 2,74 \%$.

\section{Висновки}

Аналіз результатів дослідження основних показників крові вказує на зниження функціонального стану організму качок у критичні періоди постнатального онтогенезу, окрім підвищення кількості еритроцитів лише на 14 добу життя 3 подальшим поступовим зниженням цього показника на тлі зменшення концентрації гемоглобіну до 150-добового віку в межах $11,8-12,8 \%$ ( $<<0,05)$, а також зростанням величини гематокриту крові до 240 доби життя в середньому на 10,3-39,3\% (P < 0,05) та збільшенням кількості лейкоцитів на $35,1 \%(\mathrm{P}<0,05)$ до 150 доби життя в межах 19,6-26,1 Г/л.

\section{References}

Chen, N.N., Liu, B., Xiong, P.W., Guo, Y., He, J.N., Hou, C.C., Ma, L.X., \& Yu, D.Y. (2018). Safety evaluation of zinc methionine in laying hens: Effects on laying performance, clinical blood parameters, organ development, and histopathology. Poultry Science, 97(4), 1120-1126. doi: 10.3382/ps/pex400.

Hariv, M.I., \& Gutyj, B.V. (2017). Dynamika fagocytarnoi' aktyvnosti nejtrofiliv u shhuriv za umov oksydacijnogo stresu ta dii' liposomal'nogo preparatu. Biologija tvaryn. 19(1), 119-124. doi: 10.15407/animbiol19.01.119.

Khariv, I., Gutyj, B., Hunchak, V., Slobodyuk, N., Vynyarska, A., Sobolta, A., Todoriuk, V., \& Seniv, R. (2017). The influence of brovitatoxide in conjunction with milk thistle fruits on the immune system of turkeys for eimeriozic invasion. Scientific Messenger LNUVMBT named after S.Z. Gzhytskyj, 19(73), 163168. doi:10.15421/nvlvet7334.

Khariv, M., Gutyj, B., Ohorodnyk, N., Vishchur, O., Khariv, I., Solovodzinska, I., Mudrak, D., Grymak, C., \& Bodnar, P. (2017). Activity of the T- and B-system of the cell immunity of animals under conditions of oxidation stress and effects of the liposomal drug. Ukrainian Journal of Ecology. 7(4), 536-541. doi: 10.15421/2017_157.

Kolomiec, I.A. (2013). Doslidzhennja funkcionuvannja Ti V-lanky imunitetu brojleriv na tli vakcinacii pry zastosuvanni simbiotika "Prajmiks-Bionorm P" ta rozchinu visokochistogo natriju gipohloritu. Visnik
Dnipropetrovskogo derzhavnogo agrarnogo universitetu, 1, 171-172 (in Ukrainian).

Kryshtoforova, B.V., \& Lemeshchenko, V.V. (2008). Problemy doslidzhennia ta interpretatsii morfolohii imunnykh utvoriv u ssavtsiv i ptakhiv. Visnyk Dnipropetrovskoho ahrarno-ekonomichnoho universytetu. Dnipropetrovsk, 2(1), 194-199 (in Ukrainian).

Olayemi, F.O., Arowolo, R.O.A., Saba, A.B., \& Famakinde, S.A. (2002). Effect of sex in the blood profiles of the Nigerian local duck (Anas platyrhynchos). Bulletin of Animal Health and Production in Africa, 50, 67-71.

Olubodun, J., Zulkifli, I., Hair-Bejo, M., Kasim, A., \& Soleimani, A.F. (2015). Physiological response of glutamine and glutamic acid supplemented broiler chickens to heat stress. European Poultry Science, 79, 1-12. doi: 10.1399/eps.2015.87.

Pavlova, I. (2015). Effect of probiotics on doxycycline disposition in gastro-intestinal tract of poultry. Bulgarian Journal of Veterinary Medicine, 18(3), 248-257. doi: $10.15547 /$ bjvm.908.

Stojanovskij, V.G., Kolomiec, I.A., Kamracka, O.I., \& Kolotnickij, V.A. (2012). Fiziologichnyi stan organizmu kurchat-brojleriv u kritichni vikovi periody pry zastosuvanni imunokoregujuchyh preparativ na tli vakcinacii. Naukovyi visnyk Lvivskogo nacionalnogo universitetu veterinarnoi medycyny ta biotehnologij imeni S.Z. Gzhyckogo, Serija «Veterinarni nauki», 14, 2(53), 236-239 (in Ukrainian).

Stojanovskij, V.G., Kolomiec, I.A., Garmata, L.S., \& Kamracka, O.I. (2018). Zminy morfofunkcional'nogo stanu organiv endokrynnoi ta imunnoi system perepeliv promyslovogo vyroshhuvannja za dii stresu. Fiziologichnyi zhurnal, 64(1), 25-33 (in Ukrainian).

Tel'cov, L.P. (2003). Vyrashhivanie zhivotnyh v ontogeneze dlja poluchenija naivysshej geneticheskoj produktivnosti. Svoremennye problemy i dostizhenija agrarnoj nauki v zhivotnovodstve. Baranaul, 4, 206211 (in Russian).

Vlizlo, V.V., Fedoruk, R.S., \& Ratich, I.B. (2012). Laboratorni metody doslidzhen u biologii, tvarynnyctvi ta veterynarnij medycyni: dovidnyk (in Ukrainian).

Vishhur, O.I., Ogorodnik, N.Z., Mudrak, D.I., Broda, N.A., \& Jackevich, N.A. (2010). Ontogenetichni osoblivosti gematologichnogo profilju krovi ta pokaznikiv fagocitozu $\mathrm{u}$ muskusnih kachok ta kachokbrojleriv. Naukovo-tehnichnij bjuleten Institutu biologii tvarin NAANU ta DNDKI veterinarnih preparativ ta kormovih dobavok, 11(1), 246-249 (in Ukrainian).

Wójcik, E., \& Smalec, E. (2017). Constitutive heterochromatin in chromosomes of duck hybrids and goose hybrids. Poultry Science. 96(1), 18-26. doi: $10.3382 / \mathrm{ps} / \mathrm{pew} 318$. 